\title{
A Look at Real Housing Prices and Incomes: Some I mplications for H ousing Affordability and Quality
}

J oseph G yourko and J oseph Tracy

\section{INTRODUCTION}

In the 1980s, the affordability of a single family home joined traditional housing issues such as substandard units and racial discrimination as a focal point of housing policy discussion. Despite an aging population, which should increase home ownership over time, the aggregate ownership rate declined by 1 percentage point during the 1980s. This marked a reversal of the trend over the past several decades toward higher aggregate home ownership rates.

In this paper, we update this affordability debate using data from the 1990s. We follow Gyourko and Linneman (1993) in addressing the affordability issue by asking a simple question: Is a home of a given quality from ten or twenty years ago more or less affordable today to a household similarly situated to the type of household that occupied the home a decade or two ago? It is important to determine whether the prolonged economic expansion of the 1990s has significantly improved affordability for households at the bottom of the income distribution. Real

J oseph $G$ yourko is a professor of real estate and finance at The W harton School, U niversity of P ennsylvania; J oseph Tracy is a vice president at the $F$ ederal Reserve $B$ ank of $N$ ew $Y$ ork. The views expressed are those of the authors and do not necessarily reflect the position of the $F$ ederal $R$ eserve $B$ ank of $N$ ew Y ork or the $F$ ederal R eserve System. house prices at the lower end of the price distribution fell during the 1990s. However, our concept of affordability also hinges on the trends in constant-quality house prices for which, heretofore, there have not been estimates for the current expansion.

Also in need of reexamination is Gyourko and Linneman's conclusion that housing quality at the lower end of the house price distribution is rapidly deteriorating. We introduce a new estimation technique that suggests that the quality of high-end homes may have improved more and the quality of low-end homes may have deteriorated less than has been suggested in previous research. This analysis also has implications for the Clinton Administration's desire to expand home ownership, particularly among lower income households. It strikes us as virtually impossible to tell whether or not this is a good idea without knowing whether the quality of lower end housing really is falling and, if so, if it is the deterioration's proximate cause. If the quality decline is real, and if it reflects an inability of low-income households to afford adequate maintenance, then it may be misguided to encourage more low-income households to place their weal th in owner-occupied housing. W hile we cannot answer the question here, our analysis suggests urgently needed research. 


\section{What Do We MEAN by HOUSING \\ AFFORDABILITY?}

Linneman and M egbolugbe (1992) note that how affordability is defined can have important policy consequences. For example, the most widely known affordability index, published by the $N$ ational Association of R ealtors (NAR), is constructed such that an index value of 100 implies that the median income family qualifies for the median value home. Because interest rates are more variable than incomes, changes in the NAR index over time primarily reflect variations in mortgage rates. Given current low long-term interest rates, the N AR index indicates that single family housing is now more affordable than at any time in the last twenty-five years. This is evident in Chart 1 , in which we overlay the NAR's Composite Homebuyer Affordability Index against the thirty-year fixed-rate mortgage rate. ${ }^{1}$ Improving housing affordability as measured by the NAR index points to mortgage subsidy programs and policies that act to lower long-term interest rates.

Work by J ones (1989) and Linneman and W achter (1989) implies that these policies would be insufficient to deal with the real affordability problems facing many households. These researchers have found that down payment requirements have a significant impact on the ability

Chart 1

$\mathrm{N}$ ational Association of Real tors (NAR) Housing Affordabil it y Index

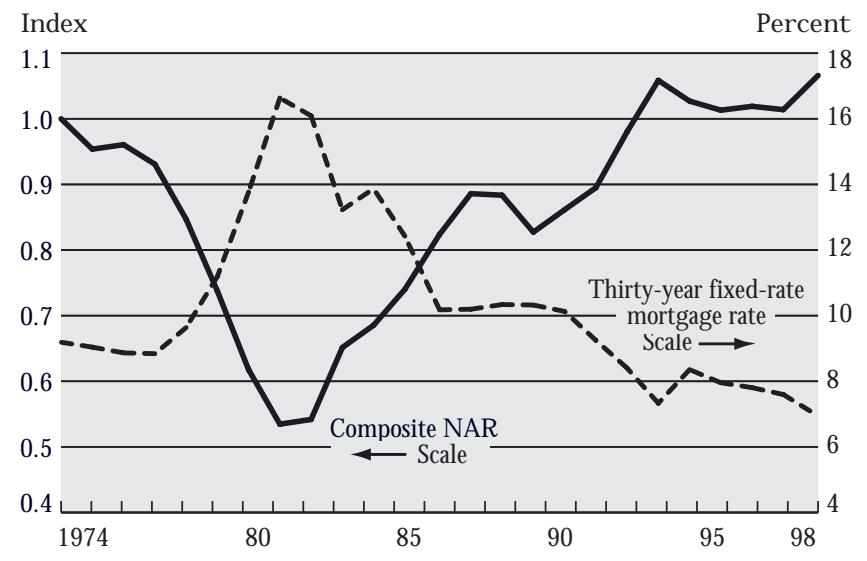

Sources: N ational A ssociation of R ealtors; Federal H ome Loan M ortgage Corporation. of many households to buy a home. W hile lower interest rates reduce the income necessary to purchase a home, they do not directly reduce the down payment requirements. As a consequence, the levels and growth rates of savings and incomes, in addition to house prices and interest rates, are key components of housing affordability. It is important, then, to move beyond the NAR affordability index.

\section{HOUSING, WAGE, AND IN COME DATA: SOURCES AN D DESCRIPTION}

The American $\mathrm{H}$ ousing Survey (AHS) series, published by the U.S. Bureau of the Census, is our primary housing data source. We report data from 1974-97. The AHS data were collected annually until 1981 and biannually afterward. ${ }^{2}$ In this study, we use only the national core files. W e define the reference home for our study to be a singlefamily, owner-occupied unit located in an urban area. M ost houses that fit our definition are detached, though city row houses and suburban town houses are included, while condominiums and cooperatives are excluded.

$\mathrm{H}$ ouse prices reflect owner-reported values. Prior to 1985 , these values are reported in interval form, with the interval boundaries changing through time. From 1985 to 1997, house values are reported in continuous form up to a top-coded amount that has been rising over time (leaving a roughly constant 4 percent of the sample per year subject to top coding). Rounding of house values is evident in the data since 1985, with clustering around multiples of $\$ 25,000$. We convert nominal house values into constant 1998 dollars by deflating by the consumer price index (CPI), less its shelter component.

The AHS data contain a wealth of information on housing quality. In order to maintain consistent quality measurements across the many years of our study, we use only a limited number of variables to construct constantquality real house prices. These are the same variables used in Gyourko and Linneman, permitting a direct comparison with the other time periods covered in that study.

Table 1 lists the twelve structural and neighborhood characteristics that we use to measure quality. Five are dichotomous dummy variables, where a val ue of 1 indicates 


\begin{tabular}{|c|c|}
\hline Trait & Description \\
\hline DETACH (detached unit status) & $\begin{array}{l}\text { Dichotomous } \\
1=\text { detached unit }\end{array}$ \\
\hline GARAGE & $\begin{array}{l}\text { Dichotomous } \\
1=\text { garage present }\end{array}$ \\
\hline CELLAR & $\begin{array}{l}\text { Dichotomous } \\
1=\text { cellar present }\end{array}$ \\
\hline CENTAIR (central air conditioning) & $\begin{array}{l}\text { Dichotomous } \\
1=\text { central air present }\end{array}$ \\
\hline CEN TCITY (central-city location) & $\begin{array}{l}\text { Dichotomous } \\
1=\text { located in central city }\end{array}$ \\
\hline A GEH SE (age of house in years) & Continuous \\
\hline BATHS (number of bathrooms) & $\begin{array}{l}\text { Polychotomous: four categories- } \\
1,1.5,2,2.5+^{\mathrm{a}}\end{array}$ \\
\hline BED ROOMS (number of bedrooms) & $\begin{array}{l}\text { Polychotomous: five categories- } \\
1,2,3,4,5+^{\mathrm{a}}\end{array}$ \\
\hline OTHROOMS (number of other rooms) & $\begin{array}{l}\text { Polychotomous: six categories- } \\
1,2,3,4,5,6+^{\mathrm{a}}\end{array}$ \\
\hline H EATSY S (heating system codes) & $\begin{array}{l}\text { Polychotomous: four categories- } \\
\text { central warm air, steam, electric, } \\
\text { other }\end{array}$ \\
\hline $\begin{array}{l}\text { HQUAL (overall structure quality } \\
\text { rating) }\end{array}$ & $\begin{array}{l}\text { Polychotomous: four categories- } \\
\text { excellent, good, fair, poor }\end{array}$ \\
\hline $\begin{array}{l}\text { N QUAL (overall neighborhood } \\
\text { quality rating) }\end{array}$ & $\begin{array}{l}\text { Polychotomous: four categories- } \\
\text { excellent, good, fair, poor }\end{array}$ \\
\hline
\end{tabular}

Source: U.S. Census Bureau, A merican H ousing Survey, national core files. aD enotes a top-coded amount.

that the housing unit contains the relevant trait. These variables reflect if the home is detached (DETACH), has a garage (GARAGE), has a basement (CELLAR), is equipped with central air conditioning (CEN TAIR), and whether the unit is located in the central city rather than in the suburbs (CEN TCITY).

Six of the quality measures are polychotomous. Three measure the number of rooms in the house (BATHS, BEDROOMS, OTHROOMS). The top codes reported for the number of rooms apply to the 1974-83 AHS files. Expanded information on the number of rooms is reported beginning in 1985. However, to maintain consistency across all years, we impose the top coding from the earlier years of the survey.

We also include controls for the type of heating system (HEATSY S). Houses that did not have a central warm air, steam, or electric system are grouped into a single category labeled "other." The final two variables are owner-reported quality ratings of the surrounding neighborhood (N QUAL) and of the overall house structure (HQUAL). For each of these variables, there are four possible quality evaluations: excellent, good, fair, and poor. ${ }^{3}$ A final variable, the age of the home (AGEHSE), is transformed to continuous form by using the midpoint of the reported interval.

We utilize family income data from two sourcesthe A H S and the M arch Current Population Surveys (CPS). The income data include all cash income received by the household head and all relatives living in the housing unit. This includes wages and sal aries, self-employment income, as well as interest income, social security, pensions, alimony, and the like. Real household and personal incomes are calculated by deflating by the overall CPI (not the CPI less shelter, as with house prices) and are expressed in 1998 dollars. ${ }^{4}$

\section{The HOMES AND THEIR OWNERS}

Table 2 provides summary statistics on the socioeconomic characteristics of households that own single-family houses. Table 3 provides summary statistics on the characteristics of their homes. For simplicity of exposition, these tables focus on three points in time- 1975, 1985, and

\begin{tabular}{lrrr}
$\begin{array}{l}\text { Table2 } \\
\text { OW N ER CHARACTERISTICS }\end{array}$ & & & \\
\hline Trait & 1975 & 1985 & 1995 \\
\hline Family income & $\$ 48,506$ & $\$ 45,474$ & $\$ 45,989$ \\
A ge of head of household & 47 & 52 & 47 \\
Race of head of household (percent) & & & \\
$\quad$ W hite & 90.7 & 90.1 & 87.7 \\
Black & 7.8 & 8.2 & 8.9 \\
Other & 1.5 & 1.7 & 3.4 \\
Sex of head of household & & & \\
(percentage male) & 84.3 & 76.4 & 70.2 \\
Marital status & & & \\
$\quad$ percentage married) & 80.5 & 71.0 & 67.5 \\
$\quad$ Education of head of & & & \\
household (percent) & & & \\
$\quad$ Elementary & 14.0 & 11.1 & 6.0 \\
Some high school & 13.2 & 10.9 & 9.0 \\
High school graduate & 34.1 & 35.0 & 29.8 \\
$\quad$ Some college & 16.7 & 17.3 & 26.3 \\
$\quad$ College graduate & 11.3 & 13.9 & 17.9 \\
$\quad$ Some graduate school + & 10.7 & 11.8 & 11.0 \\
Persons in household & 3 & 3 & 2 \\
Persons per room & 0.50 & 0.43 & 0.40 \\
\hline
\end{tabular}

Source: U.S. Census Bureau, A merican H ousing Survey, national core files. $\mathrm{N}$ ote: W eighted medians are reported for all continuous variables. 


\begin{tabular}{|c|c|c|c|}
\hline \multicolumn{4}{|c|}{$\begin{array}{l}\text { Table } 3 \\
\text { STRUCTURE CHARACTERISTICS }\end{array}$} \\
\hline Trait & 1975 & 1985 & 1995 \\
\hline Bathrooms & 1.5 & 1.5 & 2.0 \\
\hline Bedrooms & 3.0 & 3.0 & 3.0 \\
\hline H ouse size (square feet) & NA & 1,700 & 1,800 \\
\hline Lot size (square feet) & NA & 11,000 & 12,000 \\
\hline Other rooms & 3.0 & 3.0 & 3.0 \\
\hline Percentage detached units & 94.9 & 91.3 & 92.3 \\
\hline Percentage with a garage & 78.4 & 75.0 & 78.4 \\
\hline Percentage with a cellar & 56.9 & 51.4 & 49.6 \\
\hline $\begin{array}{l}\text { Percentage with central air } \\
\text { conditioning }\end{array}$ & 43.6 & 39.0 & 56.1 \\
\hline $\begin{array}{l}\text { Percentage with warm air } \\
\text { heating system }\end{array}$ & 65.5 & 62.0 & 62.7 \\
\hline Age of house & 20.5 & 20.5 & 30.5 \\
\hline \multicolumn{4}{|c|}{ H ouse quality ranking (percent) } \\
\hline Excellent & 46.3 & 59.5 & 58.9 \\
\hline Good & 45.2 & 33.6 & 36.5 \\
\hline Fair & 7.9 & 6.4 & 4.3 \\
\hline Poor & 0.6 & 0.5 & 0.3 \\
\hline \multicolumn{4}{|c|}{ N eighborhood ranking (percent) } \\
\hline Excellent & 43.8 & 55.3 & 52.7 \\
\hline Good & 44.1 & 33.7 & 38.4 \\
\hline Fair & 10.7 & 9.3 & 7.6 \\
\hline Poor & 1.4 & 1.7 & 1.3 \\
\hline Percentage in central city & 34.1 & 33.8 & 30.6 \\
\hline
\end{tabular}

Source: U.S. Census Bureau, A merican H ousing Survey, national core files. $\mathrm{N}$ ote: W eighted medians are reported for all continuous variables.

1995. The median family income data in the top row of Table 2 highlight one of the key factors precipitating the housing affordability problem identified by Gyourko and Linneman (1993). After rising by 29 percent, or 1.8 percent per annum between 1960 and 1974 (see the authors' Table 2), the real median household income of homeowners in our samples fell by $\$ 3,000$, a 6.2 percent decline, between 1975 and 1985. It remained basically unchanged between 1985 and 1995. ${ }^{5}$

To explore this issue in greater detail, Chart 2 shows the time path of real household income from the CPS data for several reference households. W e focus on fulltime workers with at least five years' potential work experience. $^{6}$ The chart presents indexed values of real household income for the 35th, 50th, 62nd, 71st, and 86th percentiles of the income distribution. We select these percentiles because they represent the household incomes in 1975 of the typical owners of homes from the 10th, 25th, 50th,
Chart 2

\section{Real Family Incomes}

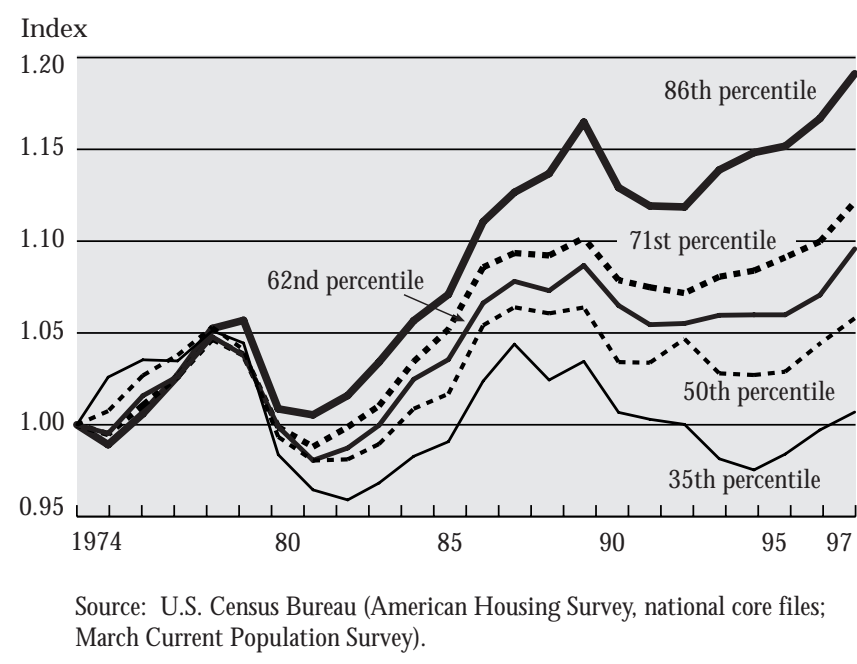

75th, and 90th percentiles of the house price distribution, respectively. ${ }^{7}$ That is, a home from the 10th percentile of the house price distribution in 1975 was likely occupied by a household with an income putting it around the 35th percentile of the overall household income distribution in that year.

The well-known increase in income inequality that occurred in the 1980s is readily apparent in Chart 2, even among the households that all have incomes high enough to support owning a home. By 1997, the index value for the 86th-percentile household is at 1.19, while the index value for the 35th-percentile household is only at 1.01, representing an 18 percent widening from the mid-1970s.

In Chart 3, we show home ownership rates over time for different household income breakdowns. W hile the ownership rate for households in the top quartile of the income distribution has been very stable, ownership rates for the three lower income quartiles have fallen over time. The extent of the ownership declines increases as you move down the income distribution. ${ }^{8}$ This chart points out that, among experienced full-time workers, declines in home ownership propensities have not been confined to those in the bottom quartile of the income distribution.

The pronounced changes in the educational achievement of homeowners identified in Gyourko and 
Linneman have continued since the mid-1980s. Owning a single-family home is increasingly associated with having more than a high school education. G yourko and Linneman reported that in 1960, 50 percent of homeowners had less than a high school education, while only 25 percent had attended college. By 1975 (column 1 of Table 2), only 27 percent of homeowners had less than a high school education, with that fraction falling to 15 percent by 1995. In contrast, by 1995,55 percent of homeowners had at least some college education, with nearly 30 percent being coll lege graduates.

Chart 4 displays home ownership rates over time by degree of educational attainment of the household head. The most precipitous fall clearly is for those without high school degrees. By 1997, the likelihood that a non-high school graduate owned a house was only 80 percent of the rate that prevailed in 1974. Even high school graduates with meaningful labor market experience now own homes at approximately 90 percent of the rate they did in the mid-1970s.

The housing qual ity information reported in Table 3 highlights the changes in the type of singlefamily unit being consumed. M edian values are reported so that the data reflect characteristics consistent with the typical home. In terms of

Chart 3

Home 0 wner ship Rates

By Real Income

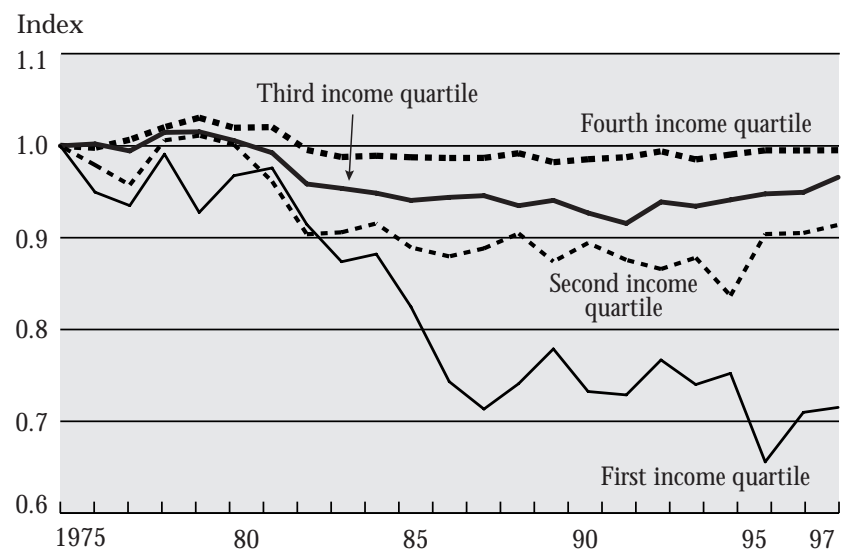

Source: U.S. Census Bureau, M arch Current Population Survey. $\mathrm{N}$ ote: $\mathrm{H}$ ouseholds must have more than five years of experience and work full-time/full-year. the number of rooms, the most significant change is in the number of bathrooms. The median number of bathrooms now is two, an increase of one half of a bathroom since $1975 .{ }^{9}$ Evidence from other sources confirms that homes and lots have become bigger over time. ${ }^{10}$

The spread of central air conditioning continues, increasing from 44 percent in 1975 to 56 percent in 1995. W hile this trait is sensitive to regional sampling, it represents a strong secular increase from the 3 percent level existing in 1960 according to U.S. Census Bureau data. Roughly two-thirds of homes had centralized warm air heating systems by 1975. W hile there has been little change since then, this al so reflects a marked rise from the 1960s (see Table 3 in Gyourko and Linneman), when most homes had room or steam heating systems. In general, the spread of centralized systems reflects their increasing presence in lower priced homes.

$\mathrm{H}$ ouse and neighborhood qual ity ratings have stabilized at their 1985 values. This marks a break in the trend identified in Gyourko and Linneman in which overall house and neighborhood quality had been consistently improving over time. Finally, the average age of the housing stock has increased. This is the only obvious dimension on which housing quality has declined over time.

\section{Chart 4}

Home 0 wnership Rat es

By Education Level

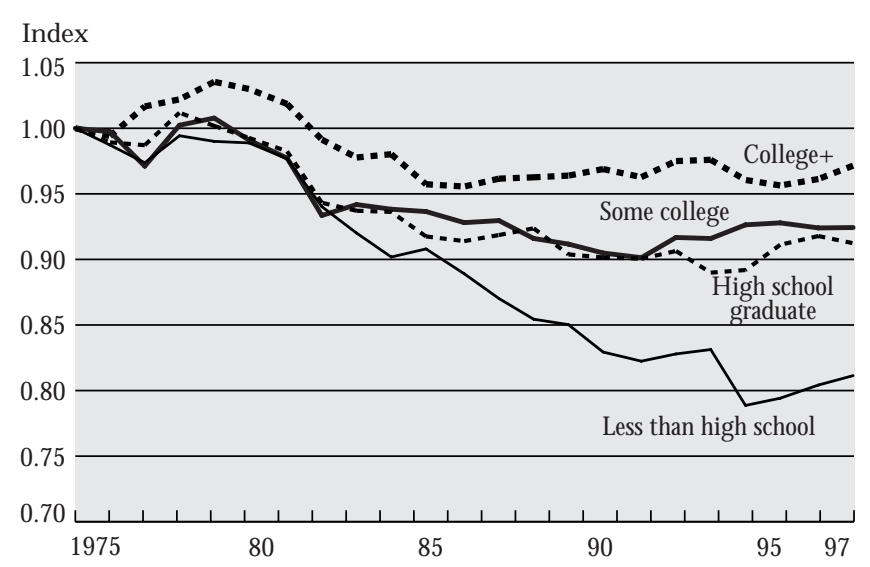

Source: U.S. Census Bureau, M arch Current Population Survey. $\mathrm{N}$ ote: $\mathrm{H}$ ouseholds must have more than five years of experience and work full-time/full-year. 


\section{Real house Price Patterns SINCE 1960}

Chart 5 plots in index form the price series for the 10th, 25th, 50th, 75th, and 90th percentiles of the real house price distribution from 1974-97. W hile Gyourko and Linneman reported that the entire price distribution of singlefamily housing shifted upward between 1960 and 1974, the same is not true since the mid-1970s. Only the real values of homes from the 75th and 90th percentiles of the price distribution have risen in real terms since 1974, with the index value in 1997 for the 75th-percentile home at 1.10 and that for the 90th-percentile home at 1.35. The median real house value in 1997 is essentially unchanged since 1974. The real price of the home from the 25th percentile in 1997 is only 89 percent of that for 1974. For the 10th-percentile home, the real price fell by an even larger 28 percent between 1974 and $1997 . .^{11}$

The widening of the real house price distribution in the 1980s parall lels the widening of the income distribution. The literature on income inequality (see Levy and Murnane [1992]) emphasizes that the spreading out of incomes has occurred both within and between different skill groups of workers. This raises the interesting question of whether the growing variance in real house prices is being driven as well by increases in both the within- and between-group variance. Following the inequality litera-

Chart 5

Real House Price Distribution

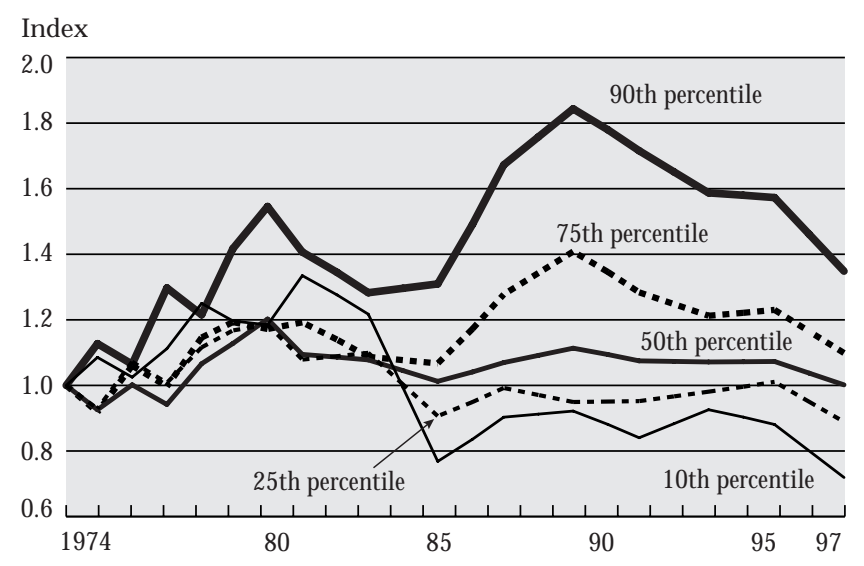

Source: U.S. Census Bureau, A merican H ousing Survey, national core files. ture, we defined household heads according to forty skill groups based on four education categories (less than high school, high school graduate, some college, and college+) and ten age categories. We found that the increased dispersion of real house prices primarily reflects increased dispersion within age/education groups. ${ }^{12}$

\section{CON STANT-Quality PRICES}

Any discussion of ownership affordability must distinguish between changes in house prices associated with house quality changes, and changes in house prices associated with price changes of constant-quality housing bundles. The following subsections present two approaches to estimating constant-qual ity price changes.

\section{A. Mean Regression Approach}

Five housing-quality packages were chosen to reflect the typical characteristics of homes in the 10th, 25th, 50th, 75th, and 90th percentiles of the price distribution as of 1974 (see the appendix). We used hedonic price regressions to price the five quality bundles, estimating the hedonic price equations separately by year. We priced the five 1974 bundles going forward from 1974 to 1997.

Equation 1 describes the regression specification estimated for each year of the AH S data (year subscripts are suppressed),

(1) $\log \left(\right.$ H $\left._{\mathrm{i}}\right)=\beta_{0}+\beta_{1}$ BATH $_{\mathrm{i}}+\beta_{2}$ BEDROOM $_{\mathrm{i}}$ $+\beta_{3}$ OTHROOM $S_{i}+\beta_{4}$ DETACH $_{i}$ $+\beta_{5}$ GARAGE $_{i}+\beta_{6}$ CELLAR $_{i}$ $+\beta_{7}$ HEATSY $_{i}+\beta_{8}$ CENTAIR $_{i}$ $+\beta_{9} \mathrm{NQUAL}_{i}+\beta_{10} \mathrm{HQUAL}_{i}$ $+\beta_{11}$ CENTCITY $_{i}+\beta_{12}$ A GEHSE $_{i}$ $+\beta_{13} A$ G EHSE $E_{i}^{2}+\varepsilon_{i}$,

where HP represents the real house price, $i$ indexes the individual observations, $\beta_{j}$ represents a coefficient or coefficient vector, the regressors correspond to the dichotomous or polychotomous variables defined in Table 1 , and $\varepsilon$ is the standard error term. By estimating the specification sepa rately by year, we allow the mean trait prices, $\beta_{\mathrm{j}}$, to reflect relative attribute price changes that were occurring over the time period. ${ }^{13}$ The underlying hedonic coefficients for 
each year do not merit discussion here and are available upon request.

The average constant-quality house prices based on the estimated mean trait prices are presented in Chart 6. This chart looks much different from the unadjusted real price series plotted in Chart 5. For the 75th- and 90th-percentile homes, constant-quality price growth has been much less than the appreciation in actual house prices. The reverse is true for the lower quality homes, in particular those at the 10th percentile.

For example, constant-quality prices for 10thpercentile houses increased by 33 percent from 1974-97, while the real price appreciation of the 10th-percentile house (whose trait bundle can change over time) fell by 28 percent. This not only indicates that the unadjusted real price series may misrepresent the affordability of a specific low- or moderate-quality house over time, but that there also may have been a serious erosion of housing quality among lower priced homes. ${ }^{14}$

A comparison of Charts 5 and 6 suggests that the quality of high-end units may have increased over the last two decades. For the 75th- and 90th-percentile homes, the unadjusted real price appreciation is substantially higher than the constant-quality price appreciation. W hile the unadjusted real price of the home from the 90th percentile

\section{Chart 6}

Const ant-Qual it y House Price Indices M ean Regression M ethod

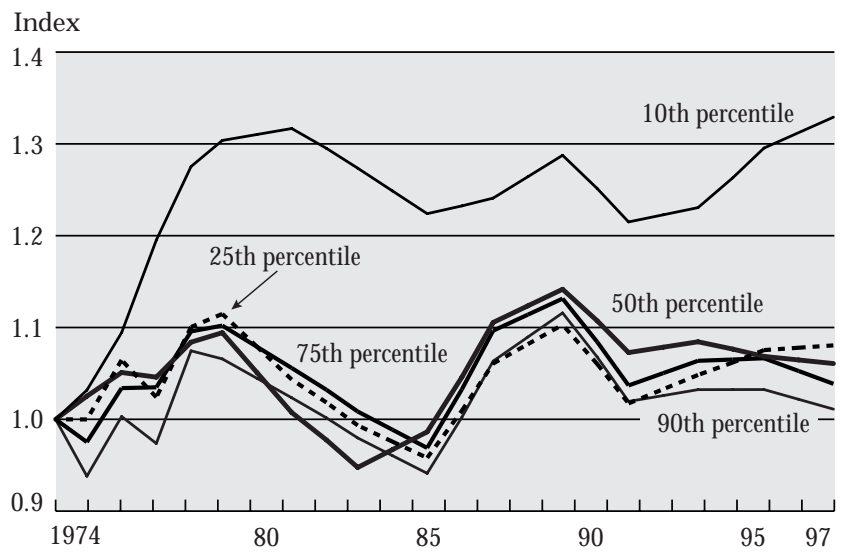

Source: U.S. Census Bureau, A merican H ousing Survey, national core files. increased by 35 percent between 1974 and 1997, the constant-quality price increased by only 1 percent.

W hether the divergence between the average constant-quality and unadjusted price indices at the lowend of the price distribution indicates deteriorating quality among lower end homes is an important question for a couple of reasons. First, the home typically is the repository of virtually all of the owner's net worth, so deteriorating quality suggests that the owners might be consuming their net worth in ways hidden to data analysts. This has potentially important implications for measured savings rates. Second, lower end homes tend to be concentrated in central cities and in older, inner-ring suburbs. A deteriorating housing stock would jeopardize the future viability of such areas, constituting an important urban policy problem.

Given the policy importance of the conclusions drawn from these results, it is important to consider the robustness of the mean regression approach in identifying differential price changes across the house price distribution. Assume, for example, that real incomes at the 75th percentile increase by 10 percent and those at the 25 th percentile decrease by 10 percent. In response to these real income changes, there is an increase in demand for highquality houses and a decrease in demand for low-quality houses. A ssume further that these changes in demand affect the overall prices of high- and low-quality houses, leaving the relative trait prices unaffected. ${ }^{15}$ With a balanced number of households demanding higher quality homes at the 75th percentile and households demanding lower quality homes at the 25th percentile, there may be no significant change in the average price of a home. ${ }^{16}$ The mean regression approach, then, may not pick up this type of divergence in constant-quality real house prices across the house-qual ity distribution.

$\mathrm{N}$ ow assume that these changes in demand affect the prices of high- and low-quality houses only through changes in the relative prices of housing traits. That is, assume that homeowners perceive some traits, say, bathrooms, as luxury items. An increase in real income for households at the upper end of the income distribution, then, will lead to an increase in the relative price of luxury 
housing traits for high-quality homes. Similar decreases in real incomes for households at the lower end of the income distribution will lead to a decrease in the relative price of these same house traits for low-quality homes. If these rela tive price changes are roughly offsetting, then there may be no significant change in the average relative prices of housing traits. Again, the mean regression approach may not pick up this divergence in constant-quality real house prices. This suggests that alternative empirical strategies may be worth exploring.

\section{B. QUANTILE REgRESSION APPROACH}

This approach borrows heavily from the mean regression methodology, but relaxes the restriction that only average trait prices are used to construct the constant-quality price indices. In the quantile regression approach, each separate price index (say, the one for the 25th percentile) is constructed using its own trait prices. The trait prices for the 25th percentile, for example, are selected so that 75 percent of actual house prices are higher than what you would predict based on the house traits and on the 25th-percentile trait prices. In addition, 25 percent of actual house prices are lower than what you would predict based on the house traits and on the 25th-percentile trait prices. If, say, bathrooms tend to contribute relatively more value to highquality homes than to low-quality homes, then this will show up as differences between the quantile-specific price for bathrooms at the upper and lower ends of the housequality distribution.

Equation 2 describes the quantile regression specification estimated for each year (and specific quantile) of the A H S data (year subscripts are suppressed),

(2) $\log \left(\mathrm{HP}_{\mathrm{i}}\right)=\beta_{q 0}+\beta_{q_{1}}$ BATHS $_{i}+\beta_{q_{2}}$ BEDROOM S $_{i}$

$$
\begin{aligned}
& +\beta_{q 3} \text { OTHROOMS }_{i}+\beta_{q 4} \text { DETACH }_{i} \\
& +\beta_{q 5} \text { GARAGE }_{i}+\beta_{q 6} \text { CELLAR }_{i} \\
& +\beta_{q 7} \text { HEATSY }_{i}+\beta_{q 8} \text { CENTAIR }_{i} \\
& +\beta_{q 9} \text { N QUAL }_{i}+\beta_{q 10} \text { HQUAL }_{i} \\
& +\beta_{q 11} \text { CENTCITY }_{i}+\beta_{q 12} \text { A GEHSE }_{i} \\
& +\beta_{q 13} \text { A GEHSE }_{i}^{2}+\varepsilon_{i},
\end{aligned}
$$

where the subscript q denotes a specific quantile (that is, the 25 th percentile).
We present in Chart 7 the constant-quality quantilespecific price indices based on the 1974 housing trait bundles and the quantile-specific price estimates from equation 2. Similar to the construction of the earlier price indices, consider the constant-quality price index value for the 25th-percentile house in year $t$. This is constructed by predicting the value of the house using the estimated 25thpercentile coefficients in year $t$ from equation 2 and the housing traits for the 25th-percentile house and dividing this by its predicted value in 1974.

W hile the two approaches to estimating constantquality price indices share many common features, some important differences emerge for the upper and lower tails of the house price distribution. Starting with the upper tail, the quantile hedonic method suggests that more rapid real price increases occurred between 1974 and 1997. The average constant-quality price index for the 90th percentile reached its peak at 1.12 in 1989, and declined to 1.01 by 1997 (Chart 6). In contrast, the 90th-percentile quantilespecific constant-quality price index reached its peak at 1.70 in 1989, and declined to 1.31 by 1997 (Chart 7). Thus, while the average hedonic measure indicates that the 90th-percentile constant-quality house prices were only 1 percent higher in 1997 than in 1974, the quantile hedonic measure suggests that they were 31 percent higher. Recall that the unadjusted real price index for the

Chart 7

Const ant-Qual it y House Price Indices Quantile Regression M ethod

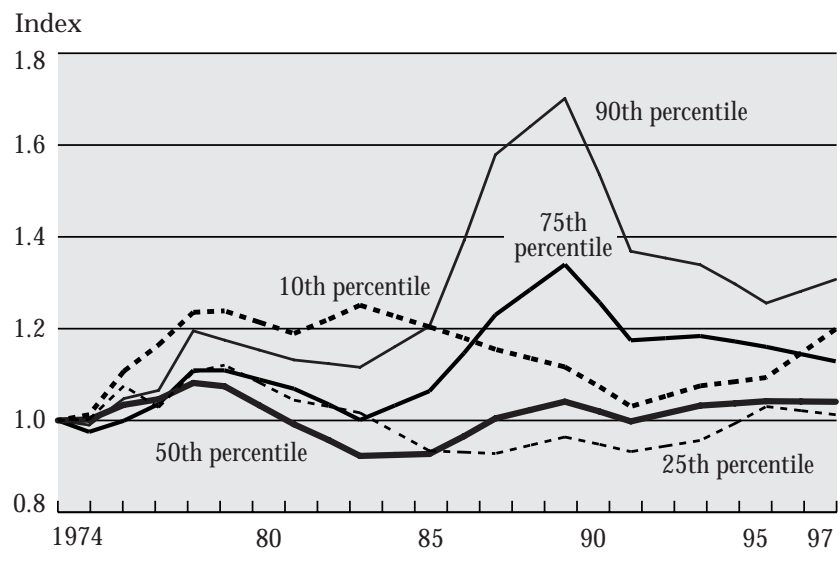

Source: U.S. Census Bureau, American H ousing Survey, national core files. 
90th-percentile house was 35 percent higher in 1997 than in 1974. The fact that both approaches to holding quality constant yield lower estimates of the real price increase at the top of the house price distribution is consistent with a general trend toward higher quality high-end houses. The increase in quality, though, looks to be considerably smaller when estimated using the quantile regression approach.

Looking at the bottom of the house price distribution, after rising 33 percent by 1981, the unadjusted real price index for the 10th percentile declined over the next sixteen years, ending up in 1997 at 28 percent below the 1974 value (Chart 5). The average hedonic price index (Chart 6) suggests that a constant-quality house at the 10th percentile was 33 percent more expensive in 1997 than in 1974. The quantile-specific hedonic price index paints a similar picture, but indicates that a constant-quality house at the 10th percentile was only 20 percent more expensivein 1997 than in 1974 (Chart 7). The fact that the 10th-percentile unadjusted real price index is well below both constant-qual ity indices suggests that average quality has worsened at the bottom of the house price distribution. A gain, the extent of the deterioration differs depending on the estimation strategy.

That said, one still needs to be careful about concluding that quality changes must underpin any differences between the unadjusted and the constant-quality price growth estimates. W hile the average hedonic method may miss demand-induced price changes, the quantile hedonic method may pick up not only demand-induced price effects, but also some quality changes. Specifically, real income declines at the bottom of the income distribution will likely lead to both direct and indirect effects on real house prices at the bottom of the house price distribution. The direct effect is that reduced real income should lead to reduced demand for housing, resulting in real price declines. The indirect effect is that reduced real income may lead to deferred and/or reduced house maintenance. This will result in a reduction in the quality of houses, which may be picked up by the quantile-specific trait prices (in particular, the intercepts of the quantile regressions). Our average and quantile hedonic methods may provide a way to bound the true unobserved constant-qual ity price indices.

\section{ReAl PRICES, ReAl In COMES, AN D \\ HOUSING QUALITY: IMPLICATIONS \\ FOR AFFORDABILITY}

Gyourko and Linneman (1993) identified a burgeoning affordability problem by the end of the 1980s for lower income households that was caused by a combination of reduced real wages (and wage growth and wage growth expectations in all probability) and increases in the real constant-quality prices of lower quality homes. W hile the N AR's affordability index suggests that home ownership opportunities have improved during the 1990s, other evidence suggests some skepticism is warranted in this regard-especially as one moves down from the median home or buyer. For example, Charts 6 and 7 show that the constant-quality price of a 10th-percentile home rose by at least 12 percent from 1991 to 1997. Constant-quality prices for 25th-percentile homes al so increased during the 1990s, but the changes have not been as great. If the real incomes of the likely occupants of these homes did not rise commensurately, then the conditions identified by Gyourko and Linneman certainly would not have abated so far in this decade.

We know from Chart 2 that households from the 35th percentile of the income distribution (likely occupants of a 10th-percentile home) have enjoyed no real income increase since 1974. In Table 4, we report real personal and household income growth tabulated from the March CPS for full-time experienced workers. The three panels break down the data by income, educational achievement, and broad occupation status. Presuming the occupants of lower quality homes tend to have below median incomes, to be less well educated, and/or to be blue collar/service workers, Table 4 documents that neither individual- nor household-level real incomes have risen in the 1990s, much less to the extent to which constant-quality housing prices rose over the decade.

These data suggest that households headed by relatively low-skilled workers manage to afford a singlefamily house only by adding the income of a second worker in the household, or by shifting further down the housing quality spectrum. In the case of the former, the household is not similarly situated to the one that consumed the same 
Table4

REAL H OUSEH OLD AN D PERSON AL In COME, 1974-97

\begin{tabular}{|c|c|c|c|c|c|c|}
\hline & \multicolumn{2}{|c|}{ 1974-81 } & \multicolumn{2}{|c|}{$1981-89$} & \multicolumn{2}{|c|}{ 1989-97 } \\
\hline & H ousehold & Personal & H ousehold & Personal & H ousehol & Personal \\
\hline \multicolumn{7}{|l|}{$\begin{array}{l}\text { Income } \\
\text { percentile }\end{array}$} \\
\hline 10th & $\begin{array}{l}-7.9 \\
(-1.2)\end{array}$ & $\begin{array}{l}-8.0 \\
(-1.2)\end{array}$ & $\begin{array}{c}5.5 \\
(0.7)\end{array}$ & $\begin{array}{c}0.3 \\
(0.04)\end{array}$ & $\begin{array}{l}-5.8 \\
(-0.7)\end{array}$ & $\begin{array}{l}-10.4 \\
(-1.4)\end{array}$ \\
\hline 25th & $\begin{array}{l}-5.8 \\
(-0.9)\end{array}$ & $\begin{array}{l}-10.1 \\
(-1.5)\end{array}$ & $\begin{array}{l}6.3 \\
(0.8)\end{array}$ & $\begin{array}{c}2.1 \\
(0.3)\end{array}$ & $\begin{array}{c}-3.5 \\
(-0.4)\end{array}$ & $\begin{array}{c}-8.5 \\
(-1.1)\end{array}$ \\
\hline 50th & $\begin{array}{l}-1.9 \\
(-0.3)\end{array}$ & $\begin{array}{c}-8.4 \\
(-1.2)\end{array}$ & $\begin{array}{c}8.5 \\
(1.0)\end{array}$ & $\begin{array}{l}5.4 \\
(0.6)\end{array}$ & $\begin{array}{l}-0.5 \\
(-0.1)\end{array}$ & $\begin{array}{l}-7.2 \\
(-0.9)\end{array}$ \\
\hline 75th & $\begin{array}{c}0.1 \\
(0.0)\end{array}$ & $\begin{array}{l}-4.8 \\
(-0.7)\end{array}$ & $\begin{array}{l}13.3 \\
(1.6)\end{array}$ & $\begin{array}{l}7.3 \\
(0.9)\end{array}$ & $\begin{array}{c}1.2 \\
(0.1)\end{array}$ & $\begin{array}{l}-4.2 \\
(-0.5)\end{array}$ \\
\hline 90th & $\begin{array}{l}-0.7 \\
(-0.1)\end{array}$ & $\begin{array}{c}-3.3 \\
(-0.5)\end{array}$ & $\begin{array}{l}17.8 \\
(2.1)\end{array}$ & $\begin{array}{l}10.5 \\
(1.2)\end{array}$ & $\begin{array}{c}3.9 \\
(0.5)\end{array}$ & $\begin{array}{c}-0.1 \\
(-0.01)\end{array}$ \\
\hline \multicolumn{7}{|l|}{ Education } \\
\hline $\begin{array}{l}\text { Less than } \\
\text { high } \\
\text { school }\end{array}$ & $\begin{array}{c}-7.8 \\
(-1.1)\end{array}$ & $\begin{array}{l}-14.0 \\
(-2.1)\end{array}$ & $\begin{array}{c}3.0 \\
(0.5)\end{array}$ & $\begin{array}{l}-2.2 \\
(-0.4)\end{array}$ & $\begin{array}{l}-0.5 \\
(-0.1)\end{array}$ & $\begin{array}{c}-2.1 \\
(-0.4)\end{array}$ \\
\hline $\begin{array}{l}\mathrm{H} \text { igh school } \\
\text { graduate }\end{array}$ & $\begin{array}{l}-7.2 \\
(-1.1)\end{array}$ & $\begin{array}{c}-12.8 \\
(-1.9)\end{array}$ & $\begin{array}{l}6.0 \\
(1.0)\end{array}$ & $\begin{array}{c}0.8 \\
(0.1)\end{array}$ & $\begin{array}{l}-1.4 \\
(-0.2)\end{array}$ & $\begin{array}{l}-7.0 \\
(-1.2)\end{array}$ \\
\hline $\begin{array}{l}\text { Some } \\
\text { college }\end{array}$ & $\begin{array}{l}-6.3 \\
(-0.9)\end{array}$ & $\begin{array}{c}-12.4 \\
(-1.9)\end{array}$ & $\begin{array}{l}8.8 \\
(1.4)\end{array}$ & $\begin{array}{c}3.5 \\
(0.6)\end{array}$ & $\begin{array}{c}0.6 \\
(0.1)\end{array}$ & $\begin{array}{c}-4.6 \\
(-0.8)\end{array}$ \\
\hline $\begin{array}{l}\text { College } \\
\text { graduate+ }\end{array}$ & $\begin{array}{l}-3.4 \\
(-0.5)\end{array}$ & $\begin{array}{c}-8.9 \\
(-1.3)\end{array}$ & $\begin{array}{l}16.5 \\
(2.6)\end{array}$ & $\begin{array}{c}9.9 \\
(1.6)\end{array}$ & $\begin{array}{l}11.1 \\
(1.8)\end{array}$ & $\begin{array}{c}8.1 \\
(1.3)\end{array}$ \\
\hline \multicolumn{7}{|l|}{ Occupation } \\
\hline $\begin{array}{l}\text { W hite- } \\
\text { collar }\end{array}$ & $\begin{array}{l}-3.1 \\
(-0.4)\end{array}$ & $\begin{array}{l}-8.8 \\
(-1.3)\end{array}$ & $\begin{array}{c}22.2 \\
(2.5)\end{array}$ & $\begin{array}{l}17.3 \\
(2.0)\end{array}$ & $\begin{array}{l}8.9 \\
(1.1)\end{array}$ & $\begin{array}{c}5.9 \\
(0.7)\end{array}$ \\
\hline Bluecollar & $\begin{array}{l}-2.8 \\
(-0.4)\end{array}$ & $\begin{array}{l}-7.0 \\
(-1.0)\end{array}$ & $\begin{array}{c}-4.0 \\
(-0.5)\end{array}$ & $\begin{array}{l}-12.1 \\
(-1.6)\end{array}$ & $\begin{array}{c}3.6 \\
(0.4)\end{array}$ & $\begin{array}{c}-4.1 \\
(-0.5)\end{array}$ \\
\hline Service & $\begin{array}{l}-12.7 \\
(-1.9)\end{array}$ & $\begin{array}{l}-20.6 \\
(-3.2)\end{array}$ & $\begin{array}{l}44.0 \\
(4.7)\end{array}$ & $\begin{array}{l}49.4 \\
(5.1)\end{array}$ & $\begin{array}{c}0.1 \\
(0.01)\end{array}$ & $\begin{array}{l}-4.1 \\
(-0.5)\end{array}$ \\
\hline
\end{tabular}

Source: U.S. Census Bureau, M arch Current Population Survey.

N otes: Cumulative real appreciation rates are reported; implied compound annual growth rates are in parentheses. $\mathrm{H}$ eads of household must have more than five years of potential experience and work full-time/full-year.

quality bundle in, say, 1974. The same holds in the latter case, because an inferior housing service flow is now being consumed. While our data and analysis are not precise enough to determine whether affordability conditions have deteriorated significantly in the 1990s, there seems to be little doubt that they have not yet improved materially at the low end of the income and house price distributions.

For the typical occupant of a home at or above the median quality, Gyourko and Linneman concluded that there is not an affordability problem in any meaningful sense. Real income gains by well-paid professionals between 1974 and 1989 tracked the constant-quality prices of high-end homes fairly cl osely - at least using their average trait price hedonic approach (Chart 6). ${ }^{17}$ Based on these data, there seems to be no compelling evidence to reject the conclusion that a similarly situated occupant of a high-end home faces an affordability situation similar to that in the mid-1970s or mid-1980s.

That said, the quantile regression results suggest that the authors' conclusion may have been premature. That is, constant-qual ity house prices rose much more during the 1980s, according to the quantile regression results depicted in Chart 7. If this reflects a much smaller quality growth than indicated by a comparison of Charts 5 and 6 , then affordability conditions during the 1980s may well have deteriorated for high-end occupants too. However, data from the 1990s suggest that things have improved on this front. Stated differently, the real incomes of households from the 75th and 90th percentiles of the income distribution rose in the 1990s, while constant-quality trait bundle prices were either flat or declining, depending on the estimation method used.

\section{CON CLUSIONS}

At least through 1997, real incomes of low-skilled workers have not fully recovered to their levels before the 1990-91 recession. With the price of a constant-quality housing bundle continuing to rise, the two primary factors that led Gyourko and Linneman to conclude that there was an affordability problem for relatively low-income occupants of lower quality homes are still present, despite the prolonged economic expansion of the 1990s.

The potential implications of these trends among low-end owners are particularly interesting. For example, the Clinton Administration is supporting a program to expand the pool of owners by at least one million households. Much of this increase will have to come from lower income households. The data presented here (suggesting that the quality of lower end homes continues to decline) point out the need for further research into whether this is in fact the case and, if so, the need to identify its causes. If the quality decline is real, and if the cause is an inability to fund adequately the maintenance of a very capital-intensive good such as housing, then encouraging lower income households to put what little wealth they do have into housing may be misguided. The true savings of these households may be negatively impacted, with further 
important implications for their retirement years and for the communities in which they live. Research is also needed into whether these owners are increasingly "locked into" their homes (see Chan [1998]). With real quality declines, home equity may not be as high as some owners think or wish. Trading up or moving may become increasingly difficult for this group.

For higher end homes and their upper-income occupants, the quantile regressions suggest that constant- quality price growth in high-quality homes was much higher than what was estimated by Gyourko and Linneman using the average regression approach. Even if their conclusion- that there was no meaningful change in affordability conditions for these households - was premature, data from the 1990s suggest that affordability conditions certainly have not deteriorated for high-income households during this decade. 
APPENDIX: 1974 TRAIT BUndLESROM FIVE PerCentiles of THE PRICE Distribution

\begin{tabular}{|c|c|c|c|c|c|}
\hline \multirow[b]{2}{*}{ Trait } & \multicolumn{5}{|c|}{ Percentile of the Price Distribution } \\
\hline & 10th & 25th & 50th & 75th & 90th \\
\hline \multicolumn{6}{|l|}{$\begin{array}{l}\text { Actual price } \\
\text { (1998 dollars) }\end{array}$} \\
\hline Bathrooms & 1.00 & 1.00 & 1.50 & 2.00 & 2.00 \\
\hline Bedrooms & 3.00 & 3.00 & 3.00 & 3.00 & 3.00 \\
\hline Other rooms & 3.00 & 3.00 & 3.00 & 3.00 & 4.00 \\
\hline D etached unit & Yes & Yes & Yes & Yes & Yes \\
\hline Garage & Yes & Yes & Yes & Yes & Yes \\
\hline Cellar & No & Yes & Yes & Yes & Yes \\
\hline H eating system & $\begin{array}{l}\text { Central } \\
\text { warm air }\end{array}$ & $\begin{array}{l}\text { Central } \\
\text { warm air }\end{array}$ & $\begin{array}{l}\text { Central } \\
\text { warm air }\end{array}$ & $\begin{array}{l}\text { Central } \\
\text { warm air }\end{array}$ & $\begin{array}{l}\text { Central } \\
\text { warm air }\end{array}$ \\
\hline $\begin{array}{l}\text { Central air } \\
\text { conditioning }\end{array}$ & No & No & No & No & No \\
\hline $\begin{array}{l}\text { A ge of house } \\
\text { (years) }\end{array}$ & 31 & 23 & 19 & 17 & 16 \\
\hline $\begin{array}{l}\text { Overall structure } \\
\text { quality }\end{array}$ & Good & Good & Excellent & Excellent & Excellent \\
\hline $\begin{array}{l}\text { Overall } \\
\text { neighborhood } \\
\text { quality }\end{array}$ & Good & Good & Good & Excellent & Excellent \\
\hline $\begin{array}{l}\text { Central-city } \\
\text { location }\end{array}$ & Yes & No & No & No & No \\
\hline
\end{tabular}

Source: U.S. Census Bureau, American H ousing Survey, national core files. 


\section{ENDNOTES}

The authors thank Richard Thompkins and $H$ enry Schneder for the r excellent research assistance Chris $M$ ayer provided insightful comments on the first draft. A ll errors are the authors' responsibility.

1. W ehave rebased the N AR index to havea val ue of 1 in 1974. This was done to make it more comparable with the American H ousing Survey data series that starts in 1974.

2. W hilethe AH Sis designed as a panel data set, with an unbroken panel existing since 1985, we treat these data as a repeated series of crosssections in our analysis.

3. Prior to 1985, there were only the four ratings categories. Subsequent ratings were on a scale of 1 to 10 , with 1 being the poorest quality. W e follow Gyourko and Linneman's (1993) method of collapsing these ten categories into the four pre-1985 categories.

4. The income and wage data understate the real resources available to many households, as cash incomes do not account for in-kind transfers that have risen appreciably since the 1960s. M oreover, nonwage benefits have become an increasingly large component of overall worker compensation. Of course, these benefits may be capitalized into wages or reflected in fewer hours worked. Gruber (1992) reports that certain mandated heal th benefits related to maternity are fully reflected in lower wages.

5. Some of the households in these samples are retired and do not have any wage income. There is a slight increase in the number of retirees in the sample over time.

6. W e selected this group to abstract from the separate affordability problems facing new entrants into the labor force and part-time employees.

7. To determine the income percentile associated with the 10thpercentile house, we selected the median family income for households living in homes between the 5th and the 15th percentiles in 1975. This income was compared with the population distribution of family incomes in 1975 derived from the CPS data in order to determine its percentile ranking. W e followed the anal ogous steps to determine the appropriate income percentile for the remaining house-quality percentiles.

8. The general drop in ownership rates relative to 1974 levels reflected in this chart and some of those below is indicative of very high ownership propensities among the retired elderly. W edo not focus on the elderly here.
9. In 1960, the median number of bathrooms was 1.0, according to decennial census data (see Gyourko and Linneman [1993]).

10. Prior to 1985, the AHS contained no information on either the lot sizes or living areas of the homes in our sample. Data on new homes compiled by the $\mathrm{N}$ ational Association of $\mathrm{H}$ ome Builders (NAHB) indicate that lot sizes and living areas increased by more than 250 square feet since the late 1970s. Median lot sizes have al so increased, to more than 10,000 square feet, but the increase here is less in percentage terms. (See Table 1 of various issues of the NAHB publication, Housing E conomics.)

11. The pattern of real house prices in the upper end of the distribution can be affected by the characteristics of new construction. W hile in any given year newly built homes account for only a small fraction of the entire stock, the cumulative effects of the consistently high quality of new homes can have a significant price impact. Our anal ysis finds that for the past two decades, thetypical new home has been more expensive than at least two-thirds of the existing housing stock in any given year. W hile this varies from year to year, there has been a slight downward trend in the rel ative quality of new construction since the mid-1970s.

12. W e can carry out this variance decomposition only from 1985, when house values are reported in continuous form.

13. W e estimate the mean trait prices using a maximum likelihood method that explicitly takes into account: the interval nature of the pre 1985 house values, thetop-coding of the post-1983 house values, and the "heaping" of the post-1983 house values at $\$ 25,000$ multiples.

14. A significant pure aging effect exists in the actual prices of lower quality homes. Because virtually no low-quality new homes have been constructed recently, the stock of homes from the 10th and 25th percentiles ages by one year each year. This is not the case for higher quality homes. For example, the mean age of homes from the 75th percentile increases by only seven years (from nineteen to twenty-six years) between 1974 and 1989. However, the aging of the low-quality housing stock over timeis not the primary cause for the disparity between the qual ity-adjusted and -unadjusted price series. For example, if we fix the quality of the 10th-percentile home in 1974 in all respects but age, its real price appreciation from 1974-97 still far exceeds real price appreciation of the 10th-percentile home. This indicates that housing quality at the low end of the price spectrum has fallen for reasons beyond the fact that lower quality homes are older in 1997 than they were in 1974. 


\section{EN DN OTES (C ontinued)}

15. That is, here we assume that the change in demand for quality housing does not result in changes in the prices of, say, bathrooms relative to other rooms.

16. This is an example of a mean-preserving spread in the house price distribution.
17. Moreover, we suspect that it is for these households that growing benefits packages have had their greatest negative effect on wages. Given the extensive noncash (and untaxed) benefits offered to many professionals, the real consumption power of these workers probably has risen much more in recent years than the pure wage data suggest. 


\section{REFERENCES}

B ailey, M. J., R. F. M uth, and H. O. N ourse. 1963. "A Regression Method for Real Estate Price Index Construction." JOURnAL OF THE AmERICAN Statistical Association 58: 933-42.

Case, B., and J. Quigley. 1991. "The Dynamics of Real Estate Prices." REVIEW OF ECONOMICSAND STATISTICS 73: 50-8.

Case, K. E., and R. J. Shiller. 1987. "Prices of Single-Family H omes since 1970: N ew Indexes for Four Cities." New England ECONOMIC REVIEW (September-O ctober): 45-56.

- - . 1989. "The Efficiency of the Market for Single-Family Homes." American Econ omic Review 79, no. 1: 125-37.

Chan, S. 1998. "Spatial Lock-In." Rutgers University W orking Paper no. 9816.

Crone, T. M, and R. P. Voith. 1992. "Estimating House Price Appreciation: A Comparison of Methods." JOURNAL OF HOUSING ECONOMICS 2, no. 4: 324-38.

G ruber, J. 1992. "State-M andated Benefits and Employer-Provided H eal th Insurance." N BER W orking Paper no. 4239.

Gyourko, J, and P. D. Linneman. 1993. "The Affordability of the American Dream: An Examination of the Last Thirty Y ears." J OURNAL OF HOUSING RESEARCH 4, no. 1: 39-72.

H endershott, P. . ., and T . G . T hi bodeau. 1990. "The R el ationship between M edian and Constant-Q uality H ouse Prices: Implications for Setting FHA Loan Limits." American Real Estate and URBan ECONOMICSASSOCIATION JOURNAL 18, no. 3: 323-34.

J ones, L. 1989. "Current W ealth and Tenure Choice." AmeriCAN ReAL ESTATE AND URBAN ECONOMICS ASSOCIATION JOURNAL 17, no. 1: $17-40$.

Kain, J., and J. Quigley. 1972. "N ote on O wner's Estimate of H ousing Value." Journal of the American Statistical AsSociation 67: 803-6.
Levy, F., and R. M urnane. 1992. "U.S. Earnings Levels and Earnings Inequality: A Review of Recent Trends and Proposed Explanations." J OURNAL OF ECONOMIC LITERATURE 30: 1333-81.

Linneman, P. D., and I. F. M egbolugbe 1992. "Housing Affordability: Myth or Reality?" URBAN StUdies 29, nos. 3-4: 369-92.

Linneman, P. D ., and S. B. W achter. 1989. "The Impacts of Borrowing Constraints on Home Ownership." American Real Estate AND URBAN ECONOMICS ASSOCIATION JOURNAL 17, no. 4: 389-402.

$\mathrm{N}$ ational A ssociation of $\mathrm{H}$ ome Builders. 1992. HOUSING ECONOMICS, VOL. 40, No. 8. W ashington, D.C.: N ational Association of Home Builders.

N ational A ssociation of Realtors. 1993. HOME SALES, VOL. 7, NO. 1. W ashington, D.C.: N ational Association of Real tors.

Peck, J, and J. A . W ilcox. 1991. "The M easurement and D eterminants of Single-Family H ouse Prices." American Real Estate and U Rban ECON OMICS ASSOCIATION JOURNAL 19, no. 3: 353-82.

Poterba, J. M . 1991. "H ouse Price Dynamics: The R ole of Tax Policy and Demography." Brookings Papers on Economic Activity, no. 2.

Thibodeau, T , G . 1992. Residential ReAL Estate PriCES: 1974-1983. M ount Pleasant, Mich.: The Blackstone Company.

U nited States Bureau of the Census. Various years. "American $\mathrm{H}$ ousing Survey." N ational core files; computer tapes from the Inter-U niversity Consortium for Political and Social Research.

- - - Various years. "Current Populaton Survey." Annual demographic files; computer tapes from the Inter-University Consortium for Political and Social Research.

- - . 1960. "United States Census Data for 1960." One-in-onethousand sample; computer tapes from the Inter-University Consortium for Political and Social Research. 